folk/ed. Derg, 2021; 27(3)-107.sayı

DOI: $10.22559 /$ folklor.1746

Araştırma makalesi/Research article

\title{
Halikarnas Balıkçısı'nda Deniz Motifleri ve Poseidon
}

\author{
Sea Motifs and Poseidon in The Fisherman of \\ Halicarnassus' Works
}

Tülin Arseven*

Öz

Cevat Şakir Kabaağaçlı Türk edebiyatının önemli yazarlarından biridir. Eserlerinde Halikarnas Balıkçısı müstearını kullanmıştır. Çünkü tarihteki adıyla Halikarnassos yani Bodrum, onun için önemli, özel bir yerdir. Hemen hemen bütün eserlerinde Bodrum ve ona özgü güzellikleri işlemiştir. Bodrum'un yanı sıra Ege Denizi ve Akdeniz ile bunların kıyılarını ve doğal güzelliklerini, insanlarıyla bir bütün olarak ele almıştır. Bu bütünün içinde insanların acıları, yaşam ve ekmek kavgaları, inanışları, anlatıları da vardır. Cevat Şakir denizi de vatanın parçası sayar. Denizi ve toprağıyla Anadolu, onun için koca bir yurttur. Edebiyatımızda Mavi Anadolu Hareketi'nin de öncülerinden olan Cevat Şakir, Batı uygarlığının köklerini Anadolu'ya dayandırır. Eserlerinde Anadolu ve Mavi Anadolu’yu bütün güzellikleriyle anlatmaya çalışır. $\mathrm{Bu}$ arada eserlerinde mitolojiye ait öğelere,

Geliş tarihi (Received): 27.03.2021 - Kabul tarihi (Accepted): 17.05.2021

* Prof.Dr., Akdeniz Üniversitesi Eğitim Fakültesi Türk Dili ve Eğitimi Anabilim Dalı. (Akdeniz University

Faculty of Education Department of Turkish Language and Education) tulinarseven@yahoo.com. 
anlatılara, söylencelere de büyük ölçüde yer verir. Yer verdiği mitolojik öğelerden biri de Poseidon'dur.

Cevat Şakir Kabaağaçlı'nın eserlerinde mitolojik bir kişilik olarak Poseidon'un nasıl yer aldığı, orijininden farklılıklar taşıyıp taşımadığı, nasıl ifadesini bulduğu meselesi bu çalışmanın ana problemidir. Cevat Şakir'in öncülük ettiği Mavi Anadolu düşüncesi, onu eserlerinde mitolojik öğelere yer veren diğer yazarlardan ayrı bir yere koymaktadır.

Buradan hareketle, nitel araştırma yöntemlerinden doküman analiziyle yapılan bu çalışmada Cevat Şakir'in eserleri Poseidon miti ve deniz motifleri odağında odağında taranmıştır.

Araştırmada deniz motiflerine ve Poseidon'a ait söylencelerin eski çağlardan günümüze varlığını sürdürme gayreti/biçimi, Halikarnas Balıkçısı'nın eserlerindeki yansıması, bir başka deyişle modern anlatıdaki izleri belirlenmeye çalışılmıştır.

Anahtar sözcükler: Poseidon, mit, Halikarnas, roman, öykü

\section{Abstract}

Cevat Şakir Kabaağaçlı is one of the important writers of Turkish Literature. In his works, he used the name Halikarnas Balıkçısı (Fisherman of Halicarnassus) as his pseudonym because Bodrum, as its historical name Halicarnassus, was a very important and special place for him. Cevat Şakir mentioned that Bodrum and its beauties in almost all of his works. Cevat Şakir handles Bodrum as well as the Aegean Sea and the Mediterranean Sea and their coasts, natural beauties and people as a whole. This whole also contains these people's pains, life struggles, fights for bread, beliefs, and narrations. Anatolia together with its sea and land is one huge homeland for him. Cevat Şakir, also one of the leaders of the Blue Nation Movement in our Literature, bases roots of Western Civilization to Anatolia. Kabaağaçlı tries to describe Anatolia and Blue Anatolia with their entire beauties. Meanwhile, his works also include quite a number of mythological elements, narrations, and legends. One of these mythological elements is Poseidon. The main problem of this study is how Poseidon takes place as a mythological character in Cevat Şakir Kabaağaçlı whether it contains differences from its original, or how Poseidon finds his expressions. The Blue Anatolia Movement, pioneered by Cevat Şakir, distinguishes Kabaağaçlı from other authors who include mythological elements in their works. Thus, in this study, document analysis which is one of the quantitative research methods is used, and the relevant resources are scanned within the scope of sea motifs and Poseidon's myths. In this research, it is tried to determine the effort or way of sea motifs and Poseidon myths to survive from the ancient era to today, and it's a reflection on Halikarnas Balıkçısı's work, in other words, to define its traces on modern narrative.

Keywords: Poseidon, myth, Halicarnassus, novel, story 


\section{Extended summary}

Cevat Şakir Kabaağaçl1, one of the important writers of Turkish Literature, wrote six novels, four storybooks, and one memory book. Moreover, he gathered his writings in the class of essays in nine books. In his Works, he used the name Halikarnas Balıkçısı (Fisherman of Halicarnassus) as his pseudonym because Bodrum, as its historical name Halicarnassus, was a very important and special place for him. At first, Bodrum, where he mandatorily stayed because of his conviction of confinement in a fortress, was just an exile place for the author; but over time, Bodrum became a lovely place for him. Cevat Şakir mentioned Bodrum and its beauties in almost all of his work. Cevat Şakir took Bodrum along with the Aegean Sea and the Mediterranean Sea and their coasts and natural beauties with their people as a whole. This whole also contains these people's pains, life struggles, fights for bread, beliefs, and narrations. Places in his Works are not limited to Aegean and Mediterranean Seas' Anatolian coasts. In novels like Uluç Reis and Turgut Reis, which are about the lives of important sailors and the great naval histories in Turkish history, the place in the setting expands from Spain to Tunis and Algeria. Therefore, time trace from the days when the Mediterranean Sea was a Turkish Lake to the era that the author lived. Aegean and Mediterranean Seas are represented with their victories, with a quite crowded group of characters like privates, fishermen fighting for bread, and sponge fishermen, but most with Cevat Şakir's love of the sea. Cevat Şakir counts the sea as a nation along with the land. Anatolia together with its sea and land is one huge homeland for him. Cevat Şakir, also one of the leaders of the Blue Nation Movement of our Literature, bases roots of Western Civilization on Anatolia. Kabaağaçl1 tries to describe Anatolia and Blue Anatolia with their entire beauties. Meanwhile, his Works also require quite an amount of mythological elements, narrations, and legends. One of these mythological elements is Poseidon. Within the scope of sea motifs, the main problem of this study is how Poseidon takes place as a mythological character in Cevat Şakir Kabaağaçlı whether it contains differences from its original, or how Poseidon finds his expressions. By all means, mentioning mythological elements or using them in literature Works is seen in other poets' and authors' Works in our literature. But the Blue Anatolia Movement, pioneered by Cevat Şakir, distinguishes Cevat Şakir from other authors on this matter. Thus, this study, made by one of the quantitative research methods document analysis, is also considered the Cevat Şakir's Blue Anatolia Thesis. At first, relevant literature/resources are scanned within the scope of Poseidon. Poseidon is a mythological creature that belongs to Greek Mythology. Poseidon is equivalent to Neptunus in Roma Mythology. Cevat Şakir also uses the word Neptunus in his Works. Poseidon is the origin of Neptunus and its nations. For this reason, the research focused on Poseidon based on the idea of Poseidon (him) being the first source of mythic narrations; accordingly, the heading and theme arrange ways how Poseidon and his myth take part are determined by scanning Cevat Şakir's work. In the study, it is preferred to use Halikarnas Balıkçısı instead of Cevat Şakir considering the books were published by using the pseudonym: Halikarnas Balıkçısı as the author. In this research, it is tried to determine the effort or way of Poseidon Myths' to survive from the ancient era to today, and 
it's a reflection on Halikarnas Balıkçısı's work, in other words, to define its traces on modern narrative. At the end of this research, it has determined two ways of using Poseidon and his narrations in Halikarnas Balıkçı's work. The first one of these is the way of using the sea to describe the characteristics of Poseidon, drawn in his mythological narratives. The Sea is, like Poseidon, an angry, though, and frightening creature. The sea tries to prevent sick sailors to be taken ashore. Sometimes, the sea takes revenge when a sea creature is abused. The second of these is directly using words like Poseidon, Neptunus, centaur, etc. to describe sailors. But, meanwhile, the myths of these presentments are not given in the books, it has expected from the readers to know the myths that symbol these notions and read it considering them. In his Works, the author represents and takes Anatolia as a whole with its people, lands, and abstract and concrete legacy. It is excepted from this study to be an example for the researchers in the matter of scrutinizing the reflection of myths, that has been told since the Ancient Eras, in the Modern Turkish Literature by using different methods.

\section{Giriş}

Cevat Şakir Kabaağaçlı (Girit-1891, İzmir-1973) yazdığı roman, öykü, anı ve denemeleri ile Türk edebiyatında önemli bir yere sahiptir. Hangi türde kaleme almış olursa olsun onun eserlerinde açık ya da örtülü biçimde eski çağların mitolojik anlatılarından izler görülür. Kültürün, tarihsel ve toplumsal belleğin sanatçıları ve edebiyatçıları, anlatıların anlatıları bir ölçüde etkileme gücü vardır. Cevat Şakir de Türk denizcilik tarihinin önemli zaferlerinden, ekmeğini denizden kazanan insanların yaşamlarından, eskiçağlara ait mitolojik anlatılardan harmanladıklarını yazıya dökmüştür. Cevat Şakir'in eserleri üzerine daha önce birçok çalışma ${ }^{1}$ yapılmıştır. Bu çalışmalar yazarın hayatı, sanatı ve eserleri üzerine bütüncül açıdan yaklaşmakta veya belirli bir romanı ya da belirli bir temayı irdelemektedir. Araştırmamız odağına mitolojik bir varlık olan Poseidon'u (/Neptunus), buna dair söylenceleri alması yönüyle Cevat Şakir üzerine yapılmış diğer çalışmalardan ayrılmaktadır. Cevat Şakir'in eserlerinde mitolojik varlık ve anlatıların bütününü ele almanın bir makalenin sınırlarını aşacağı muhakkaktır. Yazarın roman, öykü, anı ve deneme türlerinde kaleme aldığı kitaplarının sayısının yirmiyi bulması, eskiçağlara dair mitolojik kahramanların, bunlara ait söylencelerin çokluğu konuyu sınırlandırma zorunluluğu doğurmuştur. Çalışmanın eksenine Posedion mitinin alınmasında ise Cevat Şakir'in gerek eserlerinde gerekse diğer düzyazılarında denizin ve ona dair inanışların büyük yer tutması etkili olmuştur. Denizin insan yaşamında, evrenin düzenindeki yeri bir başka önemli etkendir.

Araştırmacılara göre evrenin yaratılması, Yunan dünyasında değişik, kendine özgü görünümlere bürünür; özellikle de her şeyden önce evrenin düzeninin kurulmasına aracı olan olay ya da edimi vurgular (Agizza, 2001: 14). Agizza, başlangıçta herkes ve her nesne için aynı ve değişmez bir durum olan, sonsuz uzay, karanlık boşluğun somutlaşması olan Khaos vardı ve bir çeşit ilkel bir tanrısal varlık olarak gösterilen Khaos, Düzen'den ya da öteki adıyla Evren'den (Kosmos) önce gelmişti, der. Bunu düzensizlikle, herhangi bir düzenleyici 
ilkenin yokluğuyla ilişkilendirir (Agizza, 2001: 15). Onun bu saptaması, evrenin başlangıçtan bu yana bir değişim içinde olduğunun altını çizer. Evren, dünya, toplumsal yaşam ve insan sürekli bir değişim içindedir. Hâl böyle olunca insana dair hemen her olay, olgu da değişim gösterebilir. İnsan, uygarlığ kurarken ve geliştirirken karşılaştı̆̆ 1 yeni durumlar karşısında farklı ve yeni düşünceler, davranış ve tutumlar geliştirmeyi başarmıştır. İnsanın yaşamına yön vermede belirleyici olan birçok faktör, yeni duruma göre değişir, kendini yeniler. $\mathrm{Bu}$ kaçınılmaz değişim döngüsü içinde sadece somut varlıkların değil, soyut olanların da başkalaştığı görülür. Bazen yalnızca bireyin kendi küçük dünyasına bazen de toplum yaşamına yön veren anlatılar da bu değişimden payına düşeni alır. Efsane, söylence veya mit, hangi sözcükle karşılanırsa karşılansın insanın duygu, düşünce ve inanç dünyasında bir şekilde yer bulan anlatıların zaman içinde değişimi söz konusu olur. Bu mantık üzere, Helen ve Anadolu uygarlıklarının İlkçağ mitolojik varlıklarından olan Poseidon'a ait söylencelerin de günümüzde kendini yenileyerek yaşadığını söylemek yanlış olmasa gerektir. Bu görüşten hareketle bu çalışmada Poseidon'un günümüz dünyasındaki görünümüne odaklanılmış; sözlü kültürden yansımalar taşıyan yazılı metinler esas alınmıştır. Çok sayıdaki yazılı metin evreninden ise Mavi Anadolu düşüncesiyle Türk edebiyatında farklı bir yerde duran Cevat Şakir Kabaağaçlı’nın eserleri seçilmiştir. Cevat Şakir kendisine müstear olarak Bodrum’un Antik çağlardaki ismi olan Halikarnassos’tan yola çıkarak Halikarnas Balıkçısı'nı seçmiş, eserlerinde özellikle bu coğrafyayı ve insanını anlatmıştır. Eserlerin basımında yazar olarak Halikarnas Balıkçısı müstearını kullandığından makale başlığında ve çalışmada da Cevat Şakir yerine Halikarnas Balıkçısı tercih edilmiştir. Halikarnas Balıkçısı'nın anlatılarının ana eksenini deniz, ekmeğini denizden kazanan insanlar ve onların yaşamları oluşturmuştur. Yazar, bu ana omurganın etrafını örerken yöre insanının ilk çağlardan günümüze ulaşmış inanışlarından ve bunlara dair ritüellerinden de söz eder. Bu nedenledir ki, mitolojide denizle ilişkilendirilen Poseidon'un ve ona dair söylencelerin ilk çağlardaki görüntüsünün 20. Yüzyıl'a ait edebî metinlerdeki yansımasının nasıl olduğu ana merak konusudur. Nitel araştırma yöntemlerinden doküman analiziyle yapılan bu çalışmada öncelikle Halikarnas Balıkçısı'nın bütün eserleri deniz motifleri ve Poseidon (Neptunus) odağında taranmıştır. Halikarnas Balıkçısı eserlerinde, bir kişi ya da bir olayı bazen aynen bazen de küçük değişikliklerle ancak özü aynı kalarak tekrarlamıştır. Roman kurgusu içinde geçen parçaların öyküleştiği, öykülerin romanların olay örgüsünde yer aldığı görülür. Çalışmada bu durum dikkate alınmış, bunlardan sadece araştırma konusunu öne çıkaranlara yer verilmiştir. Halikarnas Balıkçısı'nın eserlerinde Poseidon'a dair anlatıların izini sürebilmek için öncelikle ilgili literatür taranmış ve elde edilen veriler I. Bölümde kısaca verilmeye çalışılmıştır. II. Bölümde ise Halikarnas Balıkçısı'nın eserlerinde denize dair motiflerin ve Poseidon mitinin yansımaları ele alınmıştır.

\section{Poseidon miti}

Araştırmacılara göre Yunan mitolojisinin ilk büyük adı; kendisine karşı konulmaz efendi kimliğiyle dünyaya egemen olan Kronos’tu. Gaia’nın karnında gömülü kalmaktan kurtardığ1 
Titanlar onun egemenliği altında aralarında çiftler oluşturmuştu. Kronos, Reia’yla birleşti, Reia ona üç erkek (Hades, Poseidon, Zeus), üç kız (Hestia, Demeter, Hera) doğurdu (Agizza, 2001: 19). Kronos, çocuklarından birinin bir gün kendisini iktidardan edeceği kehaneti nedeniyle bütün çocuklarını yok etti. Titanları da bir şekilde kendisine karşı çıkamaz hâle getirdi. Ancak annesi Reia, Zeus'u Kronos'tan saklamayı başardı. Zeus'la Kronos arasında güç, iktidar mücadelesi başladı. Zeus, kardeşlerini Kronos’tan kurtardı. Titanların bir kısmını yanına çekti (Agizza, 2001: 19-21). Bu sırada Hades'e giyeni görünmez kılan bir zırh, Poseidon'a ise üç dişli bir yaba verildi (Agizza, 2001: 23). Poseidon pınarları fışkırtan, atları ve boğaları evcilleştirendi ve simgeleri üç dişli yaba, at, balıktı (Estin\&Laporte, 2003: 99). Atları o yaratmıştı ve at ırkının da koruyucusuydu. Kendi atlarının tunç toynakları, altın yeleleri vardı. Arabasını çeken atlar, onu karşısında süt liman olan denizler boyu taşır, derinlerdeki canavarlar sağa sola sıçrayarak ona yolunda eşlik ederdi (Bulfinch, 2012: 153). Poseidon'un karısı Amphitrite'ydi. Amphirite denizlerin muhteşem kraliçesi olmadan evvel güzel bir peri kızıydı, babası Okeanos'tu (Can, 2000: 132). Poseidon kendisinden bir şey istenecek değil, gücendirilmemesi, hoş geçinilmesi gereken bir güçtü. Ona yöneltilen dualar, herhangi bir konuya olumsuz yönde el koymasını önlemek içindi. Poseidon anlaşılması zor ve acımasız bir kişiliğe sahipti (Agizza, 2001: 124). Erhat'a göre ise ölçüsüz, dizginsiz, amansız doğanın simgesiydi (Homeros, 2018: xxiv). Eski çağlarda araştırmacılara göre bütün doğal olaylara tanrıların karıştığı kabul edilirdi (Estin\&Laporte, 2003: 12). Kaynaklarda bu genel bilgilerden başka Poseidon'a dair başka bilgilere, yapılan değerlendirmelere de rastlanmaktadır. Araştırmacı R. Agizza, Zeus'un saltanatı daha kurulmadan önce deniz ortamında yaşayan ve 'Denizin İhtiyarları' denilen birçok eski tanrının daha sonraları Poseidon'un saray çevresine katıldığını öne sürer. Bu eski tanrıların başlangıçta birincil tanrısal güce sahipken; yeni tanrısal düzenin yerine oturmasıyla bu gücün -her ne kadar bilinmezle ilgili büyü ve sihir dünyasına uzanan birtakım önemli değerler edindiyse de- genelde gerilediğini söyler. Dalgaların ve fırtınaların efendisi olan Deniz İhtiyarları'nın gemicilerin kazasız belasız karaya çıkmalarını engellemeye çalıştığını, insana dost olduklarının seyrek görüldüğünü belirtir. Denizlerin en derin yerlerinde şatafatlı konutlarda yaşayıp limanlara, koylara, adalara, kıyılara gemiler yanaşmasın diye bekçilik ettiklerini anlatır (Agizza, 2001: 132). Mitolojik anlatılarda Deniz İhtiyarları ile birlikte Nereus kızlarının varlığından da söz edilir. Agizza, anlatıda bunların görünüm değiştirme ve uzgörürlük yetenekleri bulunduğunu, Nereus kızlarının denizcilerin kurtarıcısı olduğunu belirtir (Agizza, 2001: 133). Mitolojik anlatılar, özellikle de denizlerin oluşumu ve koruyucularıyla ilgili olanları önemlidir. Deniz İhtiyarları ve Nereus kızlarına dair inanışlar, bunların aslında Poseidon'un ortaya çıkmasından önce var oldukları görüşü dikkate değer niteliktedir. Denize dair mitolojik varlıkların değişmesi, zaman içinde Poseidon'un kişiliğinde tekleşmesi; belki de uygarlığın gelişmesiyle insanların denize dair korkularının değişmesinin, belki kayık, vb. deniz araçlarının yapılmasıyla birlikte insanın karada olduğu gibi denizde de var olabilmesinin bir sonucudur.

Denizlere hükmeden Poseidon, Roma mitolojisinde Neptunus adını alır ve Roma'nın kuruluşu ile ilişkilendirilir. Troya Savaşı sonrasıAineias'ın Kartaca'ya denizyoluyla gidişinden 
söz ederken araştırmacı Thomas Bulfinch, Neptunus'un işlevine de değinir. Bulfinch'in anlatımıyla Roma mitolojisine göre Aineias'1 ve beraberindekileri taşıyan gemiler denizde yol alırken firtına çıkar. Neptunus, Juno'nun (Hera) Aineias'a olan husumetini bildiğinden fırtınanın sebebini anlar. Hemen rüzgârları geri çağırır, onları azarlayıp kovar. Sonra dalgaları yatıştırır, bulutları güneşin önünden dağıtır. Kayalara oturan gemilerden bazılarını zıpkınıyla kurtarır, Triton ve bir deniz nemfi de diğerlerinin yüzmesini sağlar (Bulfinch, 2012: 224). Neptunus'u Roma mitolojisinde Yunan mitolojisine göre daha güçlü, daha işlevsel bir şekilde görürüz. Bunda Neptunus'un Troya Savaşı'nda Troyalılara yardım etmesi, Troya'dan kurtulan Aineias'ın İtalya'ya gidip orada yeni bir uygarlık kurması büyük ölçüde etkilidir. Halikarnas Balıkçısı eserlerinde genellikle Neptunus sözcügünü tercih eder (Bu tercihte yazarın bir süre Roma'da Güzel Sanatlar Akademisi'nde eğitim görmesi etkili olsa gerektir.). Araştırmacılara göre mitler doğa güçlerini, doğaüstü yaratıkları vurgulayan hayal ürünü öykülerdir. Mitin simgesel ve kutsal bir ağırlığı olur. Yüzyıllar boyunca bu öyküler birbirinden beslenerek zenginleşmişlerdir. Başlarda kulaktan kulağa gizlice yayılıyorken zamanla kimileri, özellikle de yazarlıkla uğraşanlar mitleri kayda almışlardır (Estin\&Laporte, 2003: 1). Bu saptamanın örneklerini Halikarnas Balıkçısı'nın eserlerinde de görmekteyiz.

\section{Halikarnas Balıkçısı'nın eserlerinde deniz motifleri ve Poseidon}

Halikarnas Balıkçısı'nın eserlerinde deniz, denizciler, ekmeğini denizden kazanan insanlar önemli bir yere sahiptir. Bunda yazarın yaşamının çok büyük kısmını Bodrum ve İzmir'de geçirmiş olmasının etkisi büyüktür. Halikarnas Balıkçısı, 1891 yılında Girit’te Sadrazam Cevat Paşa'nın kardeşi tarihçi-yazar-vezir Mehmet Şakir Paşa'nın oğlu olarak dünyaya gelir. Doğduğunda babası Girit’te sefirdir. Çocukluğu babasının atandığı Atina/ Faleron'da geçer. Beş yaşında iken aile İstanbul'a taşınır (Halikarnas Balıkçısı, 2017d: 5). Girit, Atina ve İstanbul denizle iç içe olmaları nedeniyle onu etkileyen şehirlerdir. Yazarı etkileyen bir başka yer ise Bodrum'dur. Azra Erhat'a göre sürgün gittiği Bodrum'da Balıkçı bir destan yaşar (Erhat, 2008: 17). Şadan Gökovalı, Halikarnas Balıkçısı'nın gerçek bir poligot olduğunu; Grekçe, Latince, Arapça, Farsça, İngilizce, Fransızca, İtalyanca, Almanca ve İspanyolcayı çok iyi bildiğini (H.B., 1989: 9) söyler. Batı dillerine hâkimiyeti, Halikarnas Balıkçısı'ndaki zengin birikim için önemli bir kaynaktır. İnsanı acıları, korkuları, iyi ve kötü tüm yönleriyle ele alan Halikarnas Balıkçısı, bir yazısında şöyle der:

\footnotetext{
"Zavallı insanoğlu, milyonlarca yıl süresince sakıncalar, karanlıklar, fisıltılar ve bilinmezliklerle çevrili kalmıştı. Kutsal sayılan o gizemli (esrarlı) yere girerse insanı cin çarpabilirdi. İnsanın, yabanıllığı ile birlikte düşleri de için için iyilik özlemleri de vardı. Cinleri yavaş yavaş güzelleştirdi. İnsancıl yapıp kendine benzetmeye çabaladı. Ama nice insancıllaştırsa, tanrıların, gülen insan yüzlerinin ardında karanlıkları da vardı ki; oradan ölüm hortlayabilirdi. Canlı insanın canının başlıca düşmanı ölümdü. Günümüzde bile çocuklar, gecenin karanlığından, mezarların hortlaklarından korkarlar. Çünkü çocukluk, yabanıllığa en yakın çağdır” (H.B., 1984: 190, 191).
} 
Bu sözler, insanın binlerce yıllık yaşama savaşını özetler niteliktedir. İnsanı korkutan, tedirgin eden bir şeyler hep vardır. Karanlık güçlerden korkmanın arka planında insanın yaşama arzusunun, varlığını sürdürme kaygısının olduğunu anımsatır. Dikkatleri gizemli güçlerin varlığına hâlâ inanılmasına çeker. Bulamaç'ta Ege kıyılarının güzelliklerini anlatırken yazar şöyle der:

\begin{abstract}
"İnsan kıyıda gezerken her an ağaçların arasından çıkacak bir peri kızının koluna dokunacağını, kulağına bir şey fisıldayacağını sanırdı. Bunun için binlerce yıldan beri buralarda yaşamış olanlar hayali tezyinatla ormanlara orman perileri driyadları, çağlayan ve pınarlara su perileri naiyadları iskan etmişlerdi. Tanyeri ağarırken badısabanın serin soluğu denizde koyu mavi ürperişi yürütürdü. Sanki denizin denizin gülümseyen yanağında bir gamzeydi bu. Çünkü bu denizin köpüğünden sabah yıldızıyla beraber Venüs doğacaktı” (H.B., 1996: 166).
\end{abstract}

Halikarnas Balıkçısı'nın eserlerinde insan ile doğa arasındaki çatışmanın ve uyumun dile getirildiği görülür, en çok da insanın doğayı anlama, anlamlandırma çabası sezilir. Halikarnas başlıklı öyküsünde dünyanın en güzel ve en saf mavisinin Bodrum'da bulunduğunu, bu nedenle eski Helenlerin burayı deniz tanrısı Poseidon'a taht seçtiklerini söyler (H.B., 1972: 52). Yazar, tutkuyla bağlandığı Ege ve Akdeniz'i Uluç Reis, Turgut Reis gibi büyük denizcileriyle, Türk Deniz tarihinin ihtişamlı günleriyle, Mütareke yıllarının sünger avcılarıyla, özetle türlü yönleriyle anlatır. Toplumun hemen her kesiminden insanı, bütün gerçekliğiyle ele alırken pek çok kaynaktan beslenir. Türk tarihinin büyük deniz savaşları, Kıbrıs'ın Osmanlı topraklarına katılması, Cezayir ve Tunus'un düşman donanmalarına karşı savunulması gibi pek çok önemli olay bunların başında gelir. Ayrıca, Anadolu coğrafyası özellikle de Ege ve Akdeniz kıyıları, buralarda yaşayan insanların yaşam mücadeleleri Halikarnas Balıkçısı'nı besleyen damarlardır. Aldığı iyi eğitim, onun anlatılarını zenginleştiren bir başka etkendir. Mitoloji, Halikarnas Balıkçısı'nın eserlerinde dikkat çekici ölçüde yer tutmaktadır. Anadolu topraklarının inanışları, anlatıları, gelenek ve görenekleri Halikarnas Balıkçısı'nın eserlerinde bir şekilde karşımıza çıkar. Çünkü o, Anadolu'yu ve insanını binlerce yıllık geçmişiyle, söylenceleriyle bir bütün olarak görür. Nitekim bir kitabında söylencelerin dağlara taşlara, insanların gönüllerine sindiğini, onların kültür yurdu olduğunu söyler (H.B., 2008: 15). Ona göre Klasik uygarlığı, Anadolu'da kuranlar, bugün Anadolu'da yaşayan halkın uzak atalarıdır (H.B. 2017a: 9). Balıkçı, bu sözlerini Roma İmparatoru Augustos zamanında, Anadolu'da yapılan ilk nüfus sayımındaki rakamlarla, gününün nüfus verilerinin neredeyse aynı olduğu bilgisiyle desteklemeye çalışır. Doğudan gelen Türklerin Anadolu'daki nüfusa karıştıklarını, artık çürümekte olan Bizans İmparatorluğu'na kolayca üstün geldiklerini söyler. Türkçenin birçok sözcük alıntılayarak Anadolu'da genel bir dile dönüştüğü tezini öne sürer. Buradan hareketle o uygarlığın gerçek vârisleri biziz, der. Çünkü ona göre o kültür Anadolu topraklarında doğup gelişmiş, buradan Yunanistan'a geçmiştir. Halikarnas Balıkçısı, bu gerçeğin anlaşılması birçok hayırlı ve güzel sonuçlara, değişikliklere neden olabilir düşüncesindedir (H.B. 2017a: 9). Birçok örnekle 
görüşlerini desteklemeye çalışır. Ona göre Eski Çağ’ın yüksek kültüre sahip kadınlarının hepsi Anadoluludur. Bu görüşünü desteklemek için Halikarnas Kraliçesi I. Artemissia'y1, Miletoslu Aspesia'y1, Lesboslu Saffo’yu örnek verir (H.B., 2017b: 109). Onun için Anadolu ve Anadolu'ya ait her ne varsa onlar bu toprakların insanlarına, bize aittir. Eski zamanlardan beri anlatılagelen söylenceler, kullanılan sözcükler, her şey Anadolu'da doğmuştur. Dolayısıyla Poseidon da ona göre Grekçe değildir. Bir yazısında "Poseidon sözü Grekçe değildir. Zeus'un kardeşidir ve denizlerin tanrısıdır. Zeus kılıklıdır, ama onda Zeus'un vakar ve sükûneti yoktur. Çoğu kez huysuz olarak gösterilir. Elinde Zeus gibi şimşek tutmaz da, üç çatallı bir zıpkın (tridan) taşır” (H.B., 2017a: 43) der. Bu görüşünü desteklemeye çalışır. Yavanaların $^{2}$ denizi ilk kez Batı Anadolu'ya geldiklerinde gördüklerini, Anadolu'ya gelen bu Arilerin dilinde ogen sözcüğünün havadaki bulutlar ve özellikle bulutlardan yağmur biçiminde dökülen su anlamına geldiğini söyler. Eski Ari söylencesine göre bu gök suyunun içinde Savitri denen bir tanrının taht kurduğuna, bu tanrının da elindeki üç çatallı zıpkınla aşağıdaki göllerde ve ırmaklarda bazen balık avladığına inanıldığını belirtir. Denizi gören ilk Yavanların bu tanrıyı sonradan Poseidon ve Neptunus'a dönüştürdüklerini iddia eder (H.B., 2016a: 71). Roman ve öykülerinde de Poseidon'a bir şekilde yer verir. Çoğu zaman bu mitolojik varlığın, buna ilişkin söylencelerin doğrudan anlatımı görülmez. Halikarnas Balıkçısı'nın anlatılarında Homeros'un İlliada'sında veya Hesiodos'un Theogonia'sında olduğu gibi Olimpos tanrılarının, onların neden olduğu olayların doğrudan anlatımı söz konusu değildir. Poseidon ve ona dair söylenceler, bazı öğelerini korumakla birlikte büyük ölçüde değişerek işlenir. Çoğunlukla da mitolojik anlatılarda Poseidon'a dair çizilen kişilik özellikleri denize veya denizcilere yüklenerek verilir. Bazen deniz, bazen de denize ait bir durum, Poseidon'un işlevini üstlenir. Aganta Burina Burinata'da Akdeniz'in en büyük firtınası, en kuvvetli rüzgârı olan Provezza'yı bu işlevde görürüz. Romanda denizdeki yelkenlilerin ve içlerindeki denizcilerin kaderlerinin Provezza'nın, bu firtınalar imparatorunun elinde olduğu söylenir. Provezza en büyük kasırgasında bile salt şairdir, (H.B., 2016b: 87) denilir. Bulamaç’ta ise Provezza,

"Dünya zindan kesilmişti. Hava leş gibi gübre kokuyordu. Sanki devler ufuklardan beri ağır ağır zincirleri enginlerde sürükleyip getiriyorlardı. Birdenbire geminin yanı başlarından uzun uzun çığlıklar, hıçkırıklar savrulup geçti. Sanki korkunç bir faciayı görmüş cinler, saçları diken diken, gözleri patlamış, haykırışarak kaçışıyorlardı. Ege denizi uysal sayılır. Rahvan atın bazen ne yaman tekmesi olur unutulur” (H.B., 1996: 53).

sözleriyle betimlenir. Rüzgârla deniz ilişkisi, Eski Çağ anlatılarında da kendine yer bulur. Kaynaklara göre Poseidon'un oğlu Eolos, rüzgârlara ${ }^{3}$ hükmetmekte, rüzgârları salıvermekte ya da onları tulumların içine veya tunç bir duvarla çevrili yüzer bir adaya tıkmaktadır. Rüzgârlar Eolos'un oğullarıdır (Estin\&Laporte, 2003: 106). Poseidon'un Triton adında bir oğlu daha vardır ve Poseidon'la denizcilere aracılık eder (Estin\&Laporte, 2003: 117). Poseidon, Eolos veya Triton'un eski mitik anlatılarda üstlendikleri görevler, Halikarnas Balıkçısı'nın eserlerinde “deniz”de birleşir. Deniz rüzgârları tutar veya salıverir, denizcilere 
yardım eder veya onları cezalandırır. O, eserlerinde denizi kişileştirir. Bu kişileştirmede denize yüklenen özelliklerde arkaik anlatıların izleri, Poseidon’un gölgesi görülür. Aganta Burina Burinata'da denizin ölmek üzere olan denizciyi karaya vermemek için uğraştığ1, rüzgârı kestiği söylenir. Ne zaman ki hasta denizci ölür ve denize atılır, rüzgâr yeniden esmeye başlar (H.B., 2016b: 105). Benzer olarak Ötelerin Çocukları'nda, firtına sonrası Giritli denizciler “Deniz! Deniz! Zehirli deniz!/ Sen ki adamızı hep yas içinde yaşatırsın!” (H.B., 2010: 217) diye başlayan hazin bir türkü söyler. Onların bu türküleri denizin Poseidon'un yerini doğrudan aldığını düşündürür. Poseidon'un denizlere hükmeden tanrı olduğu inanışı kaybolmuş ancak hükmettiği deniz, onun yerini almış görünmektedir. Deniz, Poseidon'un elinde bir araç olmaktan çıkmış, bir bakıma onun kişiliğine büründürülmüştür. Deniz insana eziyet eden, istediğinde hırçınlaşıp insanların canlarını alan, istediğinde dinginleşip güzel yüzünü gösteren bir varlık olarak tanımlanır. Ötelerin Çocukları'nda anlatıcı vurgun yemiş bir denizciden şöyle söz eder: "Şu deniz Aliş’i vurmuştu. Elini, kolunu tutmaz etmişti. Az önce de, göz göre göre, on kişinin canına kıyacaktı. (H.B., 2010: 219). Uluç Reis’te ise “Artık şu denizler çok oluyorlard1. Şu korsanlara bir gemi, biricik av olsun göstermeyecekler miydi?” (H.B., 2017d: 97) cümleleri yer alır. Yaşasıs Deniz adlı öyküde ise, "Donmuş yüreğimin dili çözülmüştü. Bir ses: 'Duyduğun iç soğukluğu zamandan da eskidir. Deniz aldığı her insanın yüreğini bununla doldurur' (...)" (H.B., 1972: 178) ve "Deniz büyüktür, sır saklar, (...) (H.B., 1972: 180) denilir. Kişileştirilmede denizin çoğunlukla sert, acımasız tavrının altı çizilir. Bulamaç'ta bunlara hiddet eklenir. Fırtınanın ardından bir denizcinin durumu anlatılırken deniz, başı dönen bu nedenle de kayı̆̆ ve tayfayı geri vermeyi unutan bir kişiye benzetilir (H.B., 1996: 50). Denizci, deniz karşısında acizdir. Ege'nin Öfkesi adlı öyküde ise deniz, intikam alan bir varlık olarak betimlenir. Bencil yaradılışlı bir adam olan Aksi Mahmut üzerine kurulu öyküde deniz kendisine, kendisinden olana kötü davranan kişiden intikamını alır. Aksi Mahmut, yeni yavrulamış bir foku acımasızca, sopa ile vura vura öldürür. Olayın ardından Aksi Mahmut, kayığıyla denizdeyken birden dalgalar şahlanır ve adamı kıyıdaki kayalara vurur. Öykü, Aksi Mahmut'un durumunu anlatan Sabaha doğru deniz onu kumsala tükürdü... (H.B., 1972: 48) cümlesiyle son bulur. Halikarnas Balıkçısı'nın eserlerinde deniz ve insan ilişkisi hayli trajik bir görünüm arz eder. Yaşam kaynağı deniz, aynı zamanda insanın ölümüne de yol açabilmektedir. Deniz, insanlar için hem ekmek kapısı hem korkulan bir varlık hem de güzel, vazgeçilmez bir zenginliktir.

Halikarnas Balıkçısı, denize karşı büyük bir sevgi duymaktadır. Yazarın bu sevgisini çizdiği karakterlerin dilinden, türkülerinden aktardığına tanık oluruz. Son Türkü başlıklı öyküsünde Giritli bir denizcinin söylediği türküyü aktarırken denizi özgürlük simgesi, ölümsüz, son derece güzel, tatlı bir varlık olarak tanımlar (H.B., 1972: 159). Deniz bazen de güzel bir kadın olarak betimlenir. "Turgut Reis’te Deniz mavi gözlü, mavi yüzlü ve mavi saçlı bir güzeldi. Turgutca’ya 'Ben incir değil, seni istiyorum' diyordu” (H.B., 2020: 58) denilir. Denizi güzel bir kadına benzeten henüz daha çok küçük yaşta bir çocuk olan Turgut Reis'tir. Konusunu büyük Türk denizcisi Turgut Reis'in yaşamından alan bu romanda gerçekte yaşandığı varsayılan bir olay, henüz küçük bir çocuk olan Turgutça’ya (Turgut Reis) 
anlatılır. Olayı anlatan kişi, Turgutca’nın denize ve denizciliğe ilgi duyduğunu anlar. Çocuğu bu ilgisinden vazgeçirmek için bir öykü anlatır. Öykü, bir çobanın denizden ve denizcilikten anlamadığı halde bu işe kalkışmasını ve başına gelenleri konu edinir. Çoban, bütün malını satarak deniz yoluyla ticaret yapmaya, Gökova'dan aldığg inciri Mısır'a götürüp satmaya çalışır. Ancak tayfası, denizci olmadığını anladıkları çobana bir oyun oynar. İncirleri çobandan gizlice satarlar, sonra da gemiyi sallayıp fırtına süsü verirler. Fırtınadan kurtulmak için çobanın incir vermesi gerektiğini söylerler. Buna inanan çoban, incirleri denize kurtulmalık olarak verdiğini sanır. Oysa tayfa inciri çoktan gemiden çıkarmış ve satmıştır. Çoban iflas eder (H.B., 2020: 32). Özünde herkesin bildiği işi yapması gerektiği iletisi verilen bu kıssadan hissede dikkat çeken nokta, denizcilerin çobanı denizin bir kurtulmalık, canlarına karşın bir diyet istediği sözleriyle kandırmasıdır. Çobanın da denizin diyet istediği bilgisine karşı çıkmamasıdır. Denizin diyet istemesi, bu diyetin ödenmesinin gerekliliği Halikarnas Balıkçısı'nın romanlarında sık görülen bir motiftir ve insanların denizin bir şeye karşılık diyet istediğine inandıklarının altı çizilir. Deniz gibi korsanlar da ele geçirdikleri gemilerdeki insanlardan canlarına karşılık olarak bir diyet, bir bedel ödemelerini istemektedirler (H.B., 2020: 191, 192). Turgut Reis’te söylence, tarih ve kurmaca iç içe geçer.

Halikarnas Balıkçısı'nın eserlerinde dikkati çeken bir özellik de deniz canlılarıyla ilgili birtakım inanışlara yer vermesidir. Deniz Gurbetçileri'nde sünger avcıları, ava çıktıklarında denizde ilk gördükleri canlının sefere dair bir işaret verdiklerini düşünürler. Deniz gurbetçisini (bir tür kuş) görmeyi uğurlu, denizkaplumbağası görmeyi uğursuz sayarlar (H.B., 2015: 19, 20). Bunlar, romandaki denizcilerin hemen hepsinin hemfikir olduğu batıl inanışlardır. Ancak denizcilerden biri foklara dair bir inancını paylaşır. Denizci Hasan, fokların sadece uğurlu olmadığını, aynı zamanda insan olduklarını söyler. Bu düşüncede olmayıp kendisini eleştirenlere dedesinin başından geçtiğini söylediği bir olayı anlatır. Buna göre dedesi, denizde avlandığ kumların üzerinde uyuyakalır. Bir ara uyanır ve çok sayıda fokun mağaraya girdiğini görür. Foklar kumlara çıkınca üstlerindeki kürklerini çıkarmakta, insana dönüşmektedirler. Denizci, yakınında bulunan insana dönüşmüş, genç dişi bir fokun kürkünü gizlice alır. Şafakla birlikte foklar kürklerini giyip denize girer. Denizcinin kürkünü sakladığı dişi, insan olarak kalır. Buradan itibaren denizkızı olarak tanımlanan bu fok-insana denizci, âşık olur, onunla evlenir. Denizkızı, bir gün denizcinin sakladığı kürkü bulur, giyip foka dönüşür, tekrar denize döner. Denizci torunlarına fokların insan olduğunu, onlara iyi davranılması gerektiğini öğütler. Denizci, dedesinin anlattığı bu olayı, babaannesinin reddettiğini belirtir (H.B., 2015: 2224). Bu anlatı içindeki anlatı, kendini yalanlamakta, gerçek dışılığına dikkat çekmektedir. Bir canlının bir başka canlıya dönüşmesi motifi Eski Çağ anlatılarında da vardır. Poseiodon (/Neptunus)'un varlıkları değiştirme gücü olduğuna inanılmaktadır. Roma mitolojisinde Neptunus'la ilişkilendirilen Erysikhton söylencesi buna örnektir. Bulfinch'e göre Erysikhton, bir gün gövdesine adak çelenkleri asılan, Dryadlar'ın el ele tutuşup etrafında döndükleri, ulu bir ağacı keser. Bu nedenle tanrılar tarafından sürekli aç hissetmekle cezalandırılır. Bütün varlığını tüketen adam, kızını köle olarak satar. Kendisini satın alan adamdan korunmak için 
kı1z Neptunus'a yalvarır. Neptunus kızı başka canlılara dönüştürerek kurtarır (Bulfinch, 2012: 150-152). Toplumların kültürel belleklerinde görülen bu anlatıların zaman içinde genellikle gövdeleri kaybolmuş tehlike, vb. anında bir varlığın başka bir varlığa dönüşen son kısmı kalmıştır.

Günlerce karadan, ailesinden, sosyal hayattan uzak kalan denizcilerin gerçek diş1 varlıklarla ilgili anlatılar oluşturmaları doğaldır. Denizkızlarına dair oluşan söylenceler de bunlardandır. Resim, heykel başta olmak üzere bütün plastik sanatlarda, sinemada, edebiyatta kendine yer bulduğu görülen denizkızı motifi, Halikarnas Balıkçısı'nın eserlerinde de sıkça yer alır. Bir romanda denizkızları bukina ile ilişkilendirilir. Bukina, romanda içine üflenince ses veren, büyük bir şeytan kulesi olarak tanımlanır. Şeytan kulesi, kule biçimindeki deniz kabukları için kullanılır. Romanda denizciler, kendi aralarında konuşurken bukina ve bukinanın çıkardığı sese anlamlar yüklerler (H.B., 2015: 52, 53). Denizkızlarının, perilerin bukinaların içine girip uyuduklarına, bu nedenle kulağa götürülünce bukinalardan fisıltılar duyulduğuna, bunun da denizkızlarının gördükleri rüyalar olduğuna inanıldığını söylerler. Bu bilginin doğru olup olmadığını kaptanlarına sorarlar (H.B., 2015: 53). Soruya muhatap olan denizci, kendisinin gangavac1 ${ }^{4}$ olduğunu, sorunun dalgıçlara sorulması gerektiğini söyler (H.B., 2015: 53). Bu da denizin derinliklerine dalan dalgıçların basınç farkı, vb. nedeniyle sanrılar görebileceklerine bir göndermedir. Aynı romanın bir başka yerinde genç âşıklar Denizci Hamza ile Çakır Ayşe sohbet ederken denizkızlarından söz ederler. Hamza, denizkızlarının gözlerinin çakır renkli, bazen de zümrüt yeşili, saçlarının altın sarısı olduğunu söyler. Aslında bu betimlemeyle Ayşe’yi anlatmaktadır. Hamza, denizkızlarının sanıldığı gibi belden aşağısının balık olmadığını, onların da bacaklarının bulunduğunu yalnız dizlerinin altının balık pulu olduğunu öne sürer (H.B., 2015: 84). Burada denizkızlarının varlığına inanma, inandırmaya çalışma yoktur. Hamza, Ayşe’yi kıskandırmak için denizkızlarından söz etmektedir. Ötelerin Çocukları'nda roman kişilerinden Davut, bir eğlence mekânında, barda tanımış olduğu Veda adlı bir kadını gece rüyasında denizkızı olarak görür. Denizkızı görünümündeki Veda, insanlara ve hayata dair yaptığı çıkarımları dile getirir. İnsanların neyin iyi neyin kötü olduğuna dair belirlemeler yapıp yaşamı kendileri için kötü bir karabasana dönüştürmelerini eleştirir (H.B., 2010: 197). Bu romanda denizkızı, düşte görülen bir kadındır ve topluma, insanlara yaptığı eleştirilerle başka bir dünyaya ait görünmektedir. Denizkızı başlıklı öyküde ise bir denizkızıyla bir insanın evliliği anlatılır (H.B., 1972: 149-154). Deniz kenarında gördüğü bir denizkızıyla evlenen zengin bir adamın başından geçenler kurgulanır. Fantastik bir kurguya sahip olan öyküde yoksul ve güzel bir denizkızı sevmediği, yaşlı bir adamla evlendirilmiştir. Birçok öykü ve romana konu olan yoksul kızla zengin adamın mutsuz evliliğinin anlatıldığı bu metinde denizkızının benzer durumdaki kadınlara ek olarak bir sorunu daha vardır. $\mathrm{O}$ da çok sevdiği denizden uzak olarak karada yaşama zorunluluğudur. Mutsuz olan denizkızı, sonunda evini terk eder, denize ve öyküdeki ifadesiyle asıl sevdiği deniz erkeğine döner. Burada denizkızı mitolojik bir varlık olmaktan uzak, gerçek bir varlık gibi anlatılmıştır. Öyküyü farklı kılan, kadınların yaşadıkları önemli sorunlardan birini masalsı bir edayla, şiddet içermeden aktarmış olmasıdır. Özetle söylemek 
gerekirse Halikarnas Balıkçısı'nın eserlerinde denizkızının mitolojik görünümlerine uygun olarak verilmediği görülür. Azra Erhat'a göre de Yunan mitolojisinde Seirenler (Sirenler), yarı balık yarı insan değil, kuş kanatlarına sahip kadınlardır. Erhat'a göre Seirenler, zaman içinde değişerek denizkızına dönüşmüş, bunlara dair anlatılar da farklılaşmıştır (Erhat, 2019: 268).

Halikarnas Balıkçısı'nın eserlerinden bazılarında mitolojik varlıkların adları açıkça söylenmiş, ancak simgeledikleri anlamlar okuyucuya bırakılmıştır. Deniz Gurbetçileri'nde sadece bir yerde "triton" geçer ve bu, söylenceye uygun biçimdedir. Çocuk denecek yaşta olan Aliş, dalgıçlık yapmayı öğrenmek üzere denize ilk daldığında teknedeki tecrübeli denizcilerin onun sudan çıkmasını bekledikleri andaki durumları tritonlara benzetilir (H.B., 2015: 156). Tayfaların tritonlara benzetilip denizin oğulları, evlatları olarak betimlenmesi deniz ile denizcilerin bir bütün olarak görüldügünü düşündürmektedir. Bir başka romanda Paluka Mustafa adlı denizcinin kayığından denize sarkıp ayna tutması sırasındaki görüntüsü santorlara benzetilir (H.B., 2015: 231). Santor yani kentuarlar, yarı at yarı adam görünümlü mitolojik varlıklardır (Erhat, 2019: 170). Romanda denizcinin kayığı ile bütünleşmiş bir görüntü sergilediği anlatılmak istenmektedir. Kentuarlarla ilgili söylencelere bir gönderme yoktur. Ötelerin Çocukları'nda da denizci Ateşoğlu'nun son nefesini firtınalı bir denizde teknesinin dümeni başındayken vermesi Neptunus benzetmesiyle anlatılır (H.B., 2010: 216). Neptunus yaşamını, kazancını denizden çıkaran Ateşoğlu'nun ekmek kavgasında yitip gitmesinin yüceliğine vurgudur. Gülen Ada adlı öyküde Deli Davut'tun ne denli hızlı hareket ettiği anlatılırken “( ...) Neptün'ün Anfitrit’e bağıran sesinin hızıyla adalara doğru atılır (...)” (H.B., 1972: 92) denilir. Halikarnas Balıkçısı'nın eserlerinde denizcilerin tavırlarında tanrısal bir hâl bulunur.

\section{Sonuç}

Halikarnas Balıkçısı'nın eserlerinde denizin bütün güzelliği ile ve her yönüyle anlatıldığı görülür. Eski Çağ mitleri bu anlatımı önemli ölçüde zenginleştirir. Bu çalışmanın ana örgesini oluşturan Poseidon'a ve denize dair birçok motife rastlanır. Bunlar arasında en sık görülenlerden biri denizkızıdır. Eserlerde denizkızının varlığına inanma söz konusu değildir. Sözgelimi bir fokun denizkızına dönüşmesi, bir denizcinin de bu denizkızıyla evlenmesi, tanık olunmayan, bir yakınınım başından geçti şeklinde verilen, bir olay olarak anlatılır. Denizkızıyla evlenmenin gerçek dışı, uydurma bir olay olduğu vurgulanır. Denizkızı, daha çok gerçekleşmesi beklenmeyen arzuların, erişilmez bir varlığın veya hayallerin metaforu görünümündedir. Bu görünüm, Eskiçağ mitolojilerine hâkim olan Halikarnas Balıkçısı'nın da denizkızı anlatılarına temkinli yaklaştığını düşündürmektedir.

Halikarnas Balıkçısı'nın eserlerinde Hupes kuşu, deniz gurbetçileri, denizkaplumbağaları, foklar gibi gerçek deniz canlılarına dair inanışlara ve motiflere de rastlanmaktadır. Roman ve öykülerdeki denizciler genellikle bunlara inanmaktadır. Denizcilerin denize açıldıklarında ilk hangi deniz canlısını göreceklerine dikkat etmeleri, gördükleri varlığa göre seferlerinin 
bereketine veya hava koşullarına dair bir takım varsayımlarda bulunmaları bunlardandır. $\mathrm{Bu}$, eski çağlarda tanrıların insanlara birtakım işaretler verdiği düşüncesinin uzantısı olsa gerektir.

Mitolojide Poseidon; deniz ve denize dair her şeyi yöneten, büyük bir güç olarak tanımlanır. Bu mitolojik kahraman, Halikarnas Balıkçısı'nda iki şekilde görülür. İlk olarak Neptunus sözcüğüyle ve çoğunlukla bir denizciyi betimlerken karşımıza çıkar. Benzetme yönü açıklanmaz, okurun söylenceye hâkim olması, alımlamada bırakılan boşluğu tamamlaması beklenir. İkincisi mitolojik bir varlık olarak Poseidon’un sahip olduğu kişilik özelliklerinin denize yüklenerek verilmesi söz konusu olur. Burada da Posedon'un mitolojideki işlevini bilmek gerekmektedir. Mitolojide Poseidon sert, acıması, öfkesinden ve yapacaklarından korkulan bir varlıktır. Halikarnas Balıkçısı'nın eserlerinde deniz, Poseidon'un yerini alır, onun kişilik özelliklerine sahip olarak çizilir. Denizin hırçın sert karakteri, insanlara zaman zaman kötülük yapması, ölen denizciyi geri vermemek için direnmesi, güzelliği ile denizcileri cezbetmesi, rüzgârı kesmesi, bazen bol ürün verip bazen vermemesi, kendisine ait olan bir canlıya zarar verilmesi durumunda intikam alması, eski mitik anlatının çağdaş yorumudur. İlkçağlardan günümüze çeşitli nedenlerle mitolojik varlıklar, inanılırlıklarını kaybetmişlerse de bunların izleri anlatılarda kalmıştır. Bu çalışmada çok sayıdaki mitolojik varlık arasından yalnızca Poseiodon seçilmiş, bunun ve deniz motiflerinin Halikarnas Balıkçısı'nın eserlerindeki izleri sürülmüştür. Oysa mitolojik varlıklar ve bunlara dair anlatılar atasözlerinde, deyimlerde, halk oyunlarında, cenaze veya doğum/düğün/bayram vb. ile ilgili ritüellerde dönüşmüş, değişmiş biçimde yaşıyor ve edebî metinlerde de yer alıyor olabilir. Kültürel belleğin arkaik arka planını araştıran başka çalışmaların yapılması edebiyat bilimine katkı sağlayacaktır.

\section{Notlar}

1 Bu çalışmalardan bazıları şunlardır: 1. Metin Yetkin, Cevat Şakir'in Eserlerinde "Deniz" Temasına Bağlı Olarak Kimlik Sorunsalı, 2019, Yüksek lisans tezi. 2. Adem Özbek, Cevat Şakir Kabaağaçlı Hayat1-Sanatı-Eserleri Üzerine Bir Araştırma, 2018, Doktora tezi. 3. Emel Erol, Cevat Şakir Kabaağaçlı'nın Aganta Burina Burinata Romanının Kelime Kadrosunun Tespiti ve Türkçe Öğretimi Bakımından Değerlendirilmesi, 2014, Yüksek lisans tezi. 4. Derya Kılıçkaya, Halikarnas Balıkçısı ve Ahilik, Folklor/Edebiyat, Cilt 16, Say1 63, 2010/3, s.71-90.

2 Bazı kaynaklara göre Yavana, erken dönem Hint edebiyatında Yunanlı veya başka bir yabancı olarak tanımlanmaktadır. Sözcügün Achaemenian (Farsça) yazıtlarda Yauna ve Ia-ma-nu biçimlerinin görüldüğü söylenir ve Küçük Asya'daki Achaemenid Kralı Kyros tarafından M.Ö. 545'te fethedilen Asya Minor Ionlarına atfedilir (bkz. https://www.britannica.com/topic/Yavana).

3 Kaynaklara göre Yunan mitolojisinde dört rüzgâr vardır: Boreas, Zephyros, Euros, Notos. Boreas, kuzey rüzgârıdır ve Trakya'da oturur. Sakallı, çok büyük bir bedensel güce sahip kanatlı bir şeytan olarak gösterilir. Doğu rüzgârı Zephyros çoğunlukla hafif ve tatlı eser. Euros güneybatı, Notos güney rüzgârıdır (Estin\&Laporte, 2003:106).

4 Gangava: Akdeniz'de sünger avlayan kayıkların kıç tarafından dışarı sürülen sarkık torbaların adı 
(https:/terim.rehberim.gen.tr/terim/gangava-nedir E.T.: 29.05.2020) Gangavac1 ise avlanan süngerleri tekneye çekip bunlara yapılması gereken işlemleri uygulayan denizciler.

\section{Kaynakça}

Agizza, R. (2001). Antik Yunan'da mitoloji masallar ve söylenceler (Z. Z. İlkgelen, Çev.) Arkeoloji ve Sanat.

Bulfinch, T. (2012). Klasik Yunan ve Roma mitolojisi (Ö. U. Hoşafçı, Çev.) İstanbul: İnkılap. Can, Ş. (2000). Klasik Yunan mitolojisi (6. Bask1) İstanbul: İnk1lap.

Erhat, A. (2008). Mavi yolculuk (3. Basım) İstanbul: Can.

Erhat, A. (2019). Mitoloji sözlüğ̈̈ (26. Basım) İstanbul: Remzi.

Estin, C. ve Laporte, H. (2003). Yunan ve Roma mitolojisi (8. Basım). (M. Eran, Çev.) TÜBİTAK Popüler Bilim Kitapları.

Halikarnas Balıkçısı. (1973). Ege'den hikâyeler. Milliyet.

Halikarnas Balıkçısı. (1984). Hey koca yurt (3. Basım). (Ş. Gökovalı, Bas. Haz.) Ankara: Bilgi. Halikarnas Balıkçısı.(1989). Merhaba Anadolu (4. Basım). (Ş. Gökovalı, Der.) Ankara: Bilgi. Halikarnas Balıkçısı. (1996). Bulamaç. (S. Öğüt, Der; Ş. Gökovalı, Haz.) Ankara: Bilgi.

Halikarnas Balıkçısı. (2008). Anadolu efsaneleri (12. Basım). (Ş. Gökovalı, Haz.) Ankara: Bilgi. Halikarnas Balıkçısı. (2010). Ötelerin çocukları (8. Basım). (Ş. Gökovalı, Haz.) Ankara: Bilgi. Halikarnas Balıkçısı. (2012). Mavi sürgün (19. Basım). (Ş. Gökovalı, Haz.) Ankara: Bilgi.

Halikarnas Balıkçısı. (2015). Deniz gurbetçileri (8. Basım). (Ş. Gökovalı, Haz.) Ankara: Bilgi. Halikarnas Balıkçısı. (2016a). Arşipel (4. Basım). (Ş. Gökovalı, Der.) Ankara: Bilgi.

Halikarnas Balıkçısı. (2016b). Aganta burina burinata (43. Basım) Ankara: Bilgi.

Halikarnas Balıkçısı. (2017a). Anadolu tanrıları (12. Basım). (Ş. Gökovalı, Haz.) Ankara: Bilgi. Halikarnas Balıkçısı. (2017b). Anadolu’nun sesi (8. Basım). (Ş. Gökovalı, Haz.) Ankara: Bilgi. Halikarnas Balıkçısı. (2017c). Düşün yazıları (6. Basım). (A. Erhat, Haz.) Ankara: Bilgi. Halikarnas Balıkçısı. (2017d). Uluç Reis (24. Basım) Ankara: Bilgi.

Halikarnas Balıkçısı. (2020). Turgut Reis (12. Basım) Ankara: Bilgi.

Homeros. (2018). Odysseia (VII. Basım). (A. Erhat, A. Kadir- Eski Yunanca Aslından Çev.) Türkiye İş Bankası.

Özbek, A. (2018). Cevat Şakir Kabaağaçlı hayatı-sanatı-eserleri üzerine bir araştırma, Ankara, Gazi Üniversitesi Sosyal Bilimler Enstitüsü, Türk Dili ve Edebiyatı Anabilim Dalı, Basılmamış Doktora Tezi. 


\section{Elektronik kaynaklar}

https://www.britannica.com/topic/Yavana (Erişim tarihi: 27.02.2021)

https://terim.rehberim.gen.tr/terim/gangava-nedir (Erişim tarihi: 29.05.2020)

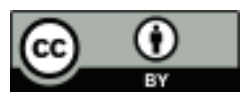

$\mathrm{Bu}$ eser Creative Commons Atıf 4.0 Uluslararası Lisansı ile lisanslanmıştır. (This work is licensed under a Creative Commons Attribution 4.0 International License). 